\title{
Media, Elections, and Ethnopolitics in Kenya: In the 2017 Elections Reportage, Ethnicity still Mattered
}

\begin{abstract}
By Michael Ndonye*
This study examined the value of ethnopolitics during media reporting of the 2017 electoral process in Kenya. The study relied on the political economy of media theory by Vincent Mosco the propaganda theory by Herman and Chomsky and the theory of agenda-setting by McCombs and Shaw. The study used descriptive research design with the population of the study drawn from Nakuru Town Sub-County. Our research relied on observation schedules to obtain data from the televised political analyses shows and propaganda political videos clip. Interview schedules were used for media practitioners (editors, reporters and media sellers) and politicians (MPs and MCAs), while unstructured questionnaires were used for the media consumers (audience). All qualitative data were processed and analysed using the critical interpretative approach, while the quantitative data were presented descriptively in tables, graphs, charts and percentages generated using SPSS software. The study findings indicated that during the 2017 electoral process in Kenya, political players used ethnopolitics to capture extensive media coverage. Similarly, there was a direct influence of ethnopolitics and ethnopolitical journalism on the media consumer knowledge and ethnopolitics normalisation. The study recommends that media, being the most influential cultural institution and player in the political economy, self-regulates to minimise ethnopolitics dissemination. The output of this study adds to the existing knowledge in communication and media studies and the political economy of mass media. The findings should be able to inform policy formulation among the mass media industry and media regulatory bodies in Kenya.
\end{abstract}

Keywords: ethnicity, ethnopolitics, ethnopolitical oligarchy, political economy of communication

\section{Introduction}

Ethnicity in Kenya is a divisive factor in politics. Political players use it to gain mileage and relevance in their ethnic constituencies and regions, while cultural institutions like media exploit it for economic gains (Ndonye et al., 2019a). The bitter truth is that ethnic consideration in elections coverage in Kenya cannot be erased with the stroke of a hand. For the purpose of this analysis, ethnopolitics is used to refer to the use of ethnicity as a resource for political behaviour manipulation and or for political entrepreneurship by politicians and media alike. The consequent end of ethnopolitics undoubtedly is domination of populous ethnic groups over others and conspicuous exclusion of minority groups from national politics. Ndonye et al. (2019b) argue that ethnopolitics is indubitably

\footnotetext{
*Head, Department of Mass Communication, Kabarak University, Kenya.
} 
responsible for ethnopolitical oligarchy establishment and sustenance going by its culturally hegemonic ability to empower a few ethnic groups and isolate others for oblivion.

The phenomenon (ethnopolitics) ensures that national resources are concentrated within a few ethnic groups. However, the gladiators of ethnopolitics are the implicit beneficiaries of the same where the media is found to be at the fore. In their quest for mass audience consolidation for sale, the mass media become direct partakers in the league of organisations that ensure institutionalisation and sustenance of ethnicity.

\section{What is the Value of Ethnopolitics?}

In the political economy of communication, the media transforms their news into services of exchange value as foregrounded by many scholars (Golding and Murdock, 2000; Mosco, 2008; Hardy, 2014) but this treatment of news is different in privately and publicly-owned media. This study recognises that private and public broadcasters, because of their different economic pursuits have varied financial cultures. A solid source to elucidate the difference is Moehler and Singh (2011), who submit that public broadcasters are not to operate like private media because of the nature of their funding because, for example, the state owns and finances the public service broadcasting. Conversely, a person owns a private broadcaster and therefore, it is through personal initiatives such as advertisements and promotional selling that they get funding (Arens et al., 2012). This financing model makes the private broadcasters to work harder and broadcast while employing many creative strategies to maximise profit through advertising.

Moehler and Singh (2011) demonstrate that the normative roles of the public broadcaster are to educate, to inform and to entertain, which are basic human needs. This justifies why public money is used to fund a state-owned broadcaster. On the contrary, private broadcaster has the freedom to expand these roles to survive in the industry (Arens et al., 2012). There are commercial establishments whose big exploit is the preferences of the public, including investigating allegations of corruption, theft, and election fraud (Oberiri, 2016). The public broadcasters give society what they need while the private broadcasters give them what they want under all costs (Oberiri, 2016). This study postulates that private media is sustained by offering more entertainment and leisure programming than the public broadcasters, which major on informational and educational roles. This nature of information, since it denoted the wants of the audience is usually expanded to other contents that the audience demands such as ethnopolitics during the electioneering period.

Since information is a driver of democracy, there is a need for multiple sources of news. Although media history shows that private media played a significant role in African independence movements, post-independent governments suppressed and literary killed private media because they aired alternative voices from the governments (Hayes and Lawless, 2015). The position is backed by Biocca (2013) who avers that most governments established monopolies in public broadcasters and used them to speak for the authoritarian governments and as a 
result, the public developed a low trust for the public broadcasters because of their relationship with the oppressive regimes. This study argues that when the public lost confidence with the public broadcasters, the government turned to public broadcasters and treated them as they wanted but manufactured consent in collaboration with the political elite to continue controlling the audience preference, tastes and opinion. The study finds the development of private broadcasting and programming interesting.

This study notes that the proliferation of privately-owned media in Kenya starting in the early 1990s (Moehler and Singh, 2011) and throughout the clamour for democracy, expanded the private media's role in the democratisation process. At this time, the private newspaper, radio and television were more vocal than the highly controlled public media. Literature shows that there was demand for greater political and civil freedoms and the governments allowed private broadcasters and airwaves to be easily accessible. Lievrouw (2011) is of the view that private media proliferates in such a milieu because they offer a rare alternative voice to the people. For example, historical accounts show that in post-independent Africa, the media industry investors avoided controversy, especially political issues, in favour of other programming such as entertainment. Later they started to allow heated political debates in their platforms. Today, private media are expected to carry more roles as outlined by Moehler and Singh (2011):

Promotion of tolerance and reconciliation in the society; provision of inclusive discussion platforms; educating citizens about their civic rights and responsibilities; mobilising; monitoring government and exposing malfeasance; informing the public about government performance; and informing policymakers about citizen interests and policy outcomes (Moehler and Singh, 2011, p. 288).

It is the view of Moehler and Singh (2011) that private media are expected to play a critical role in ensuring political and human development. He argues that with democratic regimes and relatively free press, there is a reduction of human suffering primarily through famine and other natural calamities. This way, the private media has thrived in Africa and some countries such as Kenya, private media constitutes over 90 per cent of the industry. However, it is the position of this study that the private media, as demonstrated by the televised political analyses, are today havens of ethnopolitical journalism and ethnopolitics because of the power the two have in media consumer consolidation.

More literature also shows that there have been concerns over the burgeoning of private media, especially the dramatic change of the industry's landscape from highly public to highly private dominated sector because it has come with drastic changes in the way the content, quality, distribution and ownership of media are designed (Asogwa and Asemah, 2012). Particularly, Hardy (2014) and Roush (2016) raise concern over the poor quality of information by the private media whose priority is entertainment and sensational content that has a huge following. The study also came across other scholars in the same line of argument such as Clay (2012), Cissell, (2012), Velarde (2013) and Aruguete (2017) who come to an agreement that private media have a poor quality of information content. However, this study contends these positions arguing that today, private media have high 
technology adoption, highly qualified and competent professionals unlike the public broadcasters, who suffer low innovation, minimal creativity, and thus the low quality of their output going by the situation in Kenya. The market freedom and competitive products offered by private media not only enables them to amass a strong public following and trust but also sizeable returns that have made them survive economic torrents. Since they have to compromise a lot to please the public, they appropriate the publics want and deliver content with dire consequences such as the sensational ethnic content. This background was significant in this study because it accorded the understanding of private media, where they come from, and why they operate the way they do in the industry compared to public broadcasters. It is crucial to explore then; how private media relates to the advertiser and the value, they draw from not only ethnopolitics but also from ethnopolitical journalism.

In the argument conceded by Owen (2018) and McIntosh and Shawn (2017), the media are communication bridges and sources that can reach a broad audience; and as Sonderman (2014) argues, they are mass communication outlets exemplified by radio, television, magazines and newspapers and lately all new media tools housed by the internet and all internet-enabled gadgets. This study avers, from foregoing that, connecting with a media outlet is the best way to attract customers and develop a brand in the corporate world and other circles such as politics and cultural change platforms. According to Bagdikian (2014, p. 185), "Advertising is the art of arresting the human intelligence just long enough to get money from it". Indisputably, since media became "mass media", it has become the most soughtafter highway for companies to let their target audience know about their products and services. Arens, Schaefer and Weigold (2017) concede that advertising advanced so quickly and the techniques involved enticing and shaping ideas for consumerist ideals and turning luxuries into necessities.

The utility the media draws from the content they disseminate; this study comes from the critical recognition that free media is not free because advertising subsidises it to be able to foot their bills. Stiglitz (2017) and Stroud (2011) agree that as the market competition increases, there is motivation in the mainstream media for massive expenditures on advertising. This study hypothesises that, if the above position is to go by and learning from the situation in Kenya during elections, the mainstream media is highly motivated, prepared and ready to invest massively in their content search in order to catch the massive expenditures from political advertisers. Many companies spend millions to win the hearts of the people and influence their choices towards the ideas and products. This study found that during the elections period, giant political coalitions in Kenya, such as NASA and Jubilee are ready to spend billions to influence votes and consolidate their ethnic bases. This study also argues that private media outlets attract significant political advertising because of the control of programming and coverage of critical political events and programmes that attract a mass audience.

Outstandingly, since media depend on political advertisers during the electoral period, politicians and political parties are able to exert undue influence on journalism (Cawley et al., 2011). In political advertising, the media covers the interests of the political advertiser, and they cannot ignore their preferences or 
damage the image of their advertiser. Moreover, the media considers the audience as a product for sale. In the argument of Cissell (2012), and later supported by others (Clark and Vinish, 2014; Fotis, 2015), the products that the media sells to their advertisers are the audience. This study, therefore, hypothesises that due to the power structure and relation during the electoral period, the media in Kenya where ethnicity is used for political consolidation, finds itself coming up with a kind of journalism to fit in the frame; the so-called ethnopolitical journalism that benefits both the politician and the media industry.

Exploring more of Cissell's (2012) argument, the study agrees with his position that the mass media sells space to the advertisers based on the audience they can reach and this means the more the audience you can cover or reach, the more the advertisers is willing to pay for their advertisements in a medium, and this means more revenue for the media houses. The media houses do not make money by selling newspapers or by subscriptions only. Chomsky expounds this position by asserting that:

Media corporations sell a product...They do not make money when you buy the newspaper. They are happy to put it on the World Wide Web free of charge. They actually lose money when you buy the newspaper (Chomsky, 2013).

From this, Chomsky is outright that in the business world, there must be buying and selling. That means, especially in our political scenario, if the political advertiser is the buyer, they must be buying some product and that the audience is the product. However, a deeper analysis of the literature discovers that Bagdikian (2014) treats the audience as both the consumer and the product. He argues that media is always under pressure to change content by dumping and shaping content to fit the interest and the expectations of a defined audience demographically. According to Bagdikian (2014), the content of the media is not treated as importantly as the target person. Hague (2016) has argued that this is where the philosophy of giving the audience what they want may not be the end because the media houses target the audience who can afford the advertised products. In this study, this line of thought applied to the mass media giving the political audience information that appeases their political aspirations; but as Hague (2016) argues, this may not be the case because the media will target what the political audience can afford to handle and therefore accounting for the political advertisers' money. In this line of thought, Bagdikian (2014, p.133) concludes, "Programming is carefully noncontroversial, light, and non-political". Bagdikian conclusion is not exclusive to the United States; it is what has been experienced in Kenya and the reason for private media business success. In this study, therefore, drawing from the foregoing lines of thought postulates that if that is how corporate world works and is the foundation of political advertising, media during the electoral period have no option but to be mouthpieces for the political advertiser.

Critics of media advertising (Bartman, 2016; Robinson, 2007; Schudson, 2002) agree that the influence of advertising on media content is largely seen when editors select articles on the bases of their influence to advertisements instead of the interest of the readers. This way, media houses shelve credible content and programmes because they do not support advertisements, which require a less 
framed mind full of fantasy and trivial product promotion strategies. In line with this, Bagdikian (2014) proposes that an article on social suffering; for example, interrupts and kills the buying mood on which most luxury articles rely.

Belch and Belch (2014) demonstrate that advertising falls into two categories: the paid and earned advertisements. However, these two can only apply to mainstream media advertising because the rise of the internet has led to the adoption of engine optimisation (Mendez, 2010), Facebook placement advertising and pay-per-click advertising and YouTube advertising. The internet has also provided a platform for traditional media to be online; for instance, online radio, online television, online newspapers, and online magazines (Bartman, 2016). In earned advertising, there is involvement of the word of mouth, consumer reviews, and free spots with media outlets. This is done through; for example, placements during local programs or a mention in a newspaper article. A more critical analysis of the value of paid and earned advertising can be traced to the argument of McChesney and Schiller (2003) that promotion in non-competitive markets provides a way to protect and expand commercial institutions without relying on demand and supply laws.

Reviewed literature in this study noted that Belch and Belch (2014) posit that paid advertising has both positive and negative impact. On the positive, Roush (2016) argues that through mass media, paid advertising to enable small businesses commercials to be disseminated to the mass audience within a limited time. In political advertising, branding and advertisements allow the politician or political party to attach an image or a phrase that can stick with the prospective voters for a long time. This becomes more appropriate given that, today, most media houses carry their independent research or rely on political polling reports on the voter demographics thus giving the political advertiser a better choice for their specific placements (Belch and Belch, 2014). The paid advertising is costly to place on television or other media, and in case the advert is not effective, the political advertiser suffers losses (Sachdeva, 2015). On the other hand, earned advertising is free because it depends on consumers for spreading information regarding the political product or service. This is done by word of mouth, through internet sharing and reviews on blogs. Earned advertising can go beyond the political advertiser's expectations in the form of what is said because (Ambarish and Kaiser, 2014). Politicians in Kenya depend on both but do everything to attract the free earned promotion because of their prominence. They care less about the limitation of a bad reputation in case earned advertising flops; politics is a dirty game anyway. In order to attract free media coverage, they tend to produce odd news, and this is where ethnopolitics comes on board.

The endurance of media advertising becomes more real, considering that media has devised strategies where they combine advertisements and disguise them as news (Murdock and Gripsrud, 2015; Peters, 2016). In the United Kingdom, the 2007 BBC's documentary, the Century of the Self explored the rise of consumerism in the $20^{\text {th }}$ century and argued that journalism had changed into a big business where corporations edit stories to give them more influence on the products (Ray, 2014). Many media houses would agree to editorial policies and content dictated 
by the corporate customers, including the placement of pictures, phrases and paragraphs and mention of crucial products in stories.

In addition to advertorials, Oberiri (2016) observes that the convergence between advertisement and entertainment is a more sophisticated way of doing subtle placements in some media such as films and drama. It involves bringing the promotion of a particular product as the central theme; just like the political advertiser would prefer promoting a political icon as a product. Television was an invention meant to sell to people products at the comfort of their homes, and any other role was an afterthought (Hague, 2016; Oberiri, 2016). An example was the show that gave a name to soap operas in which the main sponsors were hawking soap and had great control over the show. Likewise, this study discovered that during the 2017 electoral process in Kenya, the mainstream media especially television, was full of political operas which were driven by ethnopolitics and ethnopolitical journalism.

\section{Results and Discussion}

The section presents data from media practitioners on the value of their preference of ethnicity as a news resource even though the practice empowers dominant ethnic groups while excluding minority groups from national politics. The responses are summarised and discussed in the next sections.

\section{Preferred Media during Electoral Period}

The research sought to find out from the media sellers, the media that advertisers prefer during elections. The results are summarised in Table 1 .

Table 1. Respondents' Preference for Media by Advertisers during Election

\begin{tabular}{|c|c|c|}
\hline Media & Frequencies & Percentages \\
\hline Newspaper & 6 & $85.7 \%$ \\
\hline Radio & 4 & $57.1 \%$ \\
\hline Television & 7 & $100.0 \%$ \\
\hline Others* & 1 & $14.3 \%$ \\
\hline
\end{tabular}

Table 1 shows that 85.7 per cent and 57.1 per cent preferred newspapers and radio, respectively. Since the question was open for multiple choices, all (100 per cent), the respondents said most advertisers would prefer placing their adverts on television. 14.3 per cent of the respondents indicated that advertisers prefer other media, and this includes the online platform such as social media. These findings are in line with the declaration of the power wielded by the mainstream media and the alternative media during the electoral period; as exemplified by the 2017 period in Kenya and elsewhere. This also explains the synergy that both mainstream media and the alternative media produce in agenda-setting and propaganda modelling. Through this synergy, it is easier to dissect the mass media's political economy in reporting elections and campaigns. 
During the electoral period, advertisement falls in the two traditional categories; paid and earned advertisement (Belch and Belch, 2014). Small parties and candidates are subjected to paid advertisements which in the argument of Biocca (2013) have a positive and negative impact. According to Belch and Belch (2014) and Roush (2016), paid advertising in politics has the same effect as in the business promotion of disseminating information to the mass audience within a limited time and space. Earned political advertising, which is free, favours the parties and candidates with massive following such as Jubilee (with Uhuru Kenyatta) and NASA (with Raila Odinga). In the case of Kenya in 2017, the media gave the followers of the two political blocs unsolicited information from their political sides (Ndonye et al., 2019a; 2019b). This way, the audience acts as the agenda setter, given that the media goes for the highest good to the highest number of people - the utilitarian ideal. However, earned advertising must raise their bar above political players' expectations because if the players are not pleased, their followers will not either; and this could damage the reputation of the media and thus lose their audience base and business (Ambarish and Kaiser, 2014; Balmas and Sheafer, 2010). However, on the side of paid political advertising, in case the advertising is not effective or turns to be destructive (Sachdeva, 2015), they suffer loss and have no negotiating numbers to sanction media. This capitalist model alone works against the political lightweights in terms of cost and outcome while for political heavyweights; the capitalist system brings massive political mileage.

\section{Metrics Used to Sell Media Space and Airtime}

Our research sought to find out the system of measurement that media sellers use for advertisement space and airtime, and if the advertisers demand specific metrics before buying media space and airtime. The research captured the following three responses (coded as MR1, MR2 and MR3) whose perspective is representative of:

MR1: As for radio, most advertisers want to know the coverage areas and the number of viewers we have at specific times. The programme under which the advert is to feature is also a concern of experienced media buyers. This is important to them because it helps them compare our price scorecard with others against benefits. (Respondent, 2017)

MR2: The newspaper is static but expensive. The advertisers consider the circulation and placement of their promotional item, i.e. the page where the advert is published. (Respondent, 2017)

MR3: As for the television, it matters when and who is viewing. Since television viewership is clustered at specific times, advertising in such prime times is costly, but advertiser researches the viewership at a certain point when their promotional adverts are aired. (Respondent, 2017)

The responses MR1, MR2 and MR3 above show that audience base, circulation (for newspapers), listenership (for radio), viewership (for TV) need for 
programmes that target particular audience and the number of times that the promotion should appear are the metrics that matter for media to do business according to the media sellers engaged in this study. The respondents reported that these metrics are aligned with the advertiser demands over time, and they provide them to clients' on-demand or do the pricing. The metrics act to push media to the corner to achieve them as the mass media life lies on these market structures and commercial ideals. The pressure from the political advertiser to provide such metrics forces media houses to carry their independent research on the consumer demographics to provide the political advertiser with a better choice for their specific placements (Belch and Belch, 2014). In Kenya and Africa, the media usually hire Geopoll, which does research and provide metrics on media consumer demographics. It is for this reason that McChesney (2008, p. 3) enlists specific metrics in the political economy of media and communication systems as "shaped by ownership, market structures, commercial support, technologies, labour practices, and government policies". This was found to be true in the analyses of the Kenyan situation in the 2017 general elections reporting.

The technological advancement supplies an alternative outlet for surplus commercial inflow in mass media and provides a spillway for excesses that the mainstream media cannot handle, including extreme propaganda, political spin, and explicit ethnic innuendoes (McChesney, 2015; McChesney and Schiller, 2003). The mainstream media is supposed to self-regulate when it comes to these excesses. The reason why all television shows were uploaded on YouTube was not only for archiving purposes but to widen the audience base on which the media negotiation power can be boosted (Mendez, 2010). The two forms of advertising apply only to mainstream media because the rise of the internet and related new media such as YouTube generates the pay-per-click advertising (Bartman, 2016) thus providing a platform for the traditional media such as radio, television and newspaper to be online.

\section{Electoral Period and Prime Time in the Media Industry}

The study sought to find out whether electioneering time is prime time for business, and the responses were summarised in Table 2.

Table 2. Electoral period and Prime Time in Media Industry

\begin{tabular}{|l|c|c|}
\hline Response & Frequencies & Percentages \\
\hline Yes & 4 & $57.1 \%$ \\
\hline No & 3 & $42.9 \%$ \\
\hline Not sure & 0 & $0 \%$ \\
\hline Total & $\mathbf{7}$ & $\mathbf{1 0 0 \%}$ \\
\hline
\end{tabular}

Table 2 data summary indicates that 57.1 per cent of the responses were in agreement that during elections campaigns, there is a lot of business for media. One respondent said: 
MR4: There is a lot of news content. The period is peak since the audience needs most of the news/updates. The public is in high demand for political updates. At this time, viewers look for information about their preferred candidates. The political temperatures usually are very high. (Respondent, 2018)

However, there was no much significant deviation from those who said that the elections period is not prime time for the media houses citing that:

MR5: Most politicians ride on free publicity we give them because of what they say, to whom, with whom and whom they associate with. For example, most politicians benefit from party ads and promotions by affiliation. (Respondent, 2018)

Asked how they determine their charges in case the metrics change, the respondents gave various responses ranging from reducing the prices to encourage more viewers given the fact that a fall in demand calls for a drop in prices. A respondent reported that: In most cases, a decline in metrics usually is due to competitors' strength, and therefore prices must be dropped to cope with such a situation.

The responses to the question indicate that the electoral period is a peak time for mass media industry with 57.1 per cent of the respondents reporting that the advertising business increased during elections campaigns and towards elections day. During elections, there is a lot of political content for political parties and contestants to clarify, fake news and propaganda to counter, and many promises to make and outdo. Since the majority of politicians and political parties opt for mass media, political advertising and promotion is the big onetime harvest for the media all over the world. This is because, within a short time, destinies are shaped, power is exchanged, and influence transferred.

\section{Strategies used to Ensure Audience Base Stability}

The research inquired from the respondents the strategies they used to ensure their audience was stable and consistent, and they gave various responses. Audience base is the number of people devoted to media as listeners, viewers or readers and is established through research. The strategies mentioned by each of the respondents listed without repetition are:

i. Provision of competitive programming.

ii. Having credible content.

iii. Having contents required by the audience.

iv. Creative programming that attracts more viewership.

v. Having credible, trusted, and reliable new sources.

vi. Ensuring there are appealing programmes.

The strategies are a normative function of the successful media business, and they apply across media as observed by Tsimonis and Dimitriadis (2014). The research sought to establish some facts regarding media content, audience 
preference and advertiser demand and the results are as shown in Table 3 where $\mathrm{SD}=$ Strongly Disagree; $\mathrm{D}=$ disagree; $\mathrm{N}=$ Neutral; A=Agree; SA=Strongly Agree.

Table 3. Statements Regarding Broadcast Content

\begin{tabular}{|l|c|c|c|c|c|c|}
\hline Statements & SD & D & N & A & SA & Total \\
\hline $\begin{array}{l}\text { The audience tends to } \\
\text { like news/content } \\
\text { related to ethnicity } \\
\text { during election } \\
\text { campaigns }\end{array}$ & $\begin{array}{c}0 \\
(0.0 \%)\end{array}$ & $\begin{array}{c}0 \\
(0.0 \%)\end{array}$ & $\begin{array}{c}1 \\
(14.3 \%)\end{array}$ & $\begin{array}{c}2 \\
(28.6 \%)\end{array}$ & $\begin{array}{c}4 \\
(57.1 \%)\end{array}$ & $\begin{array}{c}7 \\
(100 \%)\end{array}$ \\
\hline $\begin{array}{l}\text { We tend to give the } \\
\text { audience what they } \\
\text { like to consume }\end{array}$ & $\begin{array}{c}0 \\
(0.0 \%)\end{array}$ & $\begin{array}{c}0 \\
(0.0 \%)\end{array}$ & $\begin{array}{c}0 \\
(0.0 \%)\end{array}$ & $\begin{array}{c}1 \\
(14.3 \%)\end{array}$ & $\begin{array}{c}6 \\
(85.7 \%)\end{array}$ & $\begin{array}{c}7 \\
(100 \%)\end{array}$ \\
\hline $\begin{array}{l}\text { During elections, the } \\
\text { political advertisers } \\
\text { demand implicitly } \\
\text { some form of } \\
\text { coverage and } \\
\text { preference }\end{array}$ & $\begin{array}{c}0 \\
(0.0 \%)\end{array}$ & $\begin{array}{c}0 \\
(0.0 \%)\end{array}$ & $\begin{array}{c}0 \\
(0.0 \%)\end{array}$ & $\begin{array}{c}3 \\
(42.9 \%)\end{array}$ & $\begin{array}{c}(57.1 \%) \\
(100 \%)\end{array}$ \\
\hline
\end{tabular}

Table 3 shows that 57.1 per cent of the respondents strongly agreed that the audience tends to like news/content related to ethnicity during election campaigns. Another 85.7 per cent strongly agreed that media tend to give the audience what they want to consume. 57.1 per cent strongly agreed that during elections, the political advertisers demand, rather implicitly, some form of coverage and preference. Given these responses, there comes a time when the audience and the advertiser set the agenda for the media instead of the other way round. This means, if ethnicity is normalised and accepted by the electorate, they demand ethnic content from the media. Since the advertisers prefer advertising on the media, which has more audience, the media will supply ethnic content to their audience to keep them. This way, the media is caught without options but to look for what the audience demands and wants. Moreover, given that the media tends to give the audience what they wish to have, the findings indicate that the mass media supply to the audience what they like to consume, which during the electoral period is ethnopolitical content. Given the traditional wisdom that the customer is to be treated like a king, the media consider the audience as their product (commodity) and customer at the same time and are thus, highly valued. Clark and Vinish (2014) posit that the products that the media sells to the advertiser are the audience and the product that it gives to the audience is the content. The position supports Cissell's (2012) observation that the media sells space to the advertisers based on the audience they can reach; meaning, the more the audience the media can reach, the more the advertisers are willing to pay for promotional placement.

The findings further show that it is not only the audience who determine, albeit implicitly, the type of content; the political advertisers (political parties, coalitions, alliances and individual candidates) demand some form of coverage and preference implicitly. The finding concurs with scholars such as Bartman (2016), Robinson (2007) and Schudson (2002) who agree that editors select 
articles based on the influence they will have on the advertising section. Thus, the media must give content favouring their target advertiser; in this case, the political advertiser because from them, they expect business deals.

\section{Conclusion}

Given the agenda-setting theory, sometimes considering the interest of the advertiser over that of the audience has positive effect because once the media filters what interests their political advertiser, the audience takes it as what matters and they will be comfortable with it provided the content resonates with their interests. In Kenya, the media targets stories that favour the political sides with the majority of the following, they are assured that the majority audience will form their audience base. Seen in this interplay is the synergy that the media, audience, and advertiser have on the construction and sustenance of ethnopolitical oligarchy of the majority five ethnic groups, which mostly form binary political coalitions.

As also postulated by Messing and Weisel (2017), it is noted in Kenya that the mainstream media, especially the five big media corporations scramble for this audience and since balance does not win critical numbers in electoral journalism (as intimated by Bravo, 2010), they chose to take partisan positions, implicitly or explicitly during electoral period. Thus, the political economy of mass media is explainable from the structures, commodification of specific audience and ethnic content that is the most sensational in the country and during elections campaigns. It is this ethnicity that mass media in Kenya exploited during the 2017 general elections, analysed from the lenses of political economy. It was not the first time and it is prospected that media will continue to exploit the same in future.

\section{References}

Ambarish, C., Kaiser, U. (2014). Targeted advertising in magazine markets and the advent of the internet. Management Science, 60(7), 1829-1843.

Arens, W., Schaefer, D. M., Weigold, A. (2017). M: Advertising. $3^{\text {rd }}$ Edition. London: McGraw-Hill/Irwin.

Arens, W., Weigold, M., Arens, C. (2012). Contemporary advertising: integrated marketing communications. $14^{\text {th }}$ Edition. London: McGraw-Hill Education.

Aruguete, N. (2017). The agenda-setting hypothesis in the new media environment. Comunicación y Sociedad 0188-252X(28), 35-58.

Asogwa, C. E., Asemah, E. (2012). News commercialisation, objective journalism practice and the sustenance of democracy in Nigeria. Higher Education of Social Science, 3(2), 27-34.

Bagdikian, B. H. (2014). The new media monopoly: a completely revised and updated edition with seven chapters. $20^{\text {th }}$ Edition. Boston: Beacon Press.

Balmas, M., Sheafer, T. (2010). Candidate image in election campaigns: attribute agendasetting, affective priming, and voting intentions. International Journal of Public Opinion Research, 22(2), 204-229. 
Bartman, G. (2016). Four ways the economist uses cross-media data to sell the audience to advertisers. Retrieved from: http://4-ways-the-econo mist-uses-cross-media-datato-sell-audience-to-advertisers/. [Accessed 20 July 2017.]

Belch, G. E., Belch, M. A. (2014). Advertising and promotion: an integrated marketing communications perspective. $10^{\text {th }}$ Edition. Boston: McGraw-Hill.

Biocca, F. (2013). Television and political advertising, volume 1: psychological processes. New York: Routledge.

Bravo, J. (2010). Towards an electoral journalism. Mundo Electoral-Electoral World, 3(8).

Cawley, J., Avery, R., Eisenberg, M. (2011). The effect of advertising and deceptive advertising on consumption: the case of over-the-counter weight loss products. New York: Cornell University, Ithaca.

Chomsky, N. (2013). Necessary illusions: thought control in democratic societies. $2^{\text {nd }}$ Edition. London: Pluto Press.

Cissell, M. (2012). Media framing: a comparative content analysis on mainstream and alternative news coverage of Occupy Wall Street. The Elon Journal of Undergraduate Research in Communications, 3(1), 67-77.

Clark, J., Vinish, S. (2014). Five reasons post media sells advertisers on the audience it can deliver, not the platform. Retrieved from: https://www.inma.org/blogs/value-con tent/post.cfm/5-reasons-postmedia-sells-advertisers-on-the-audience-it-can-delivernot-the-platform. [Accessed 20 July 2017.]

Clay, J. (2012). The information diet: a case for conscious consumption. Sebastopol, CA: O'Reilly Media.

Fotis, J. (2015). The use of social media and its impacts on consumer behaviour: the context of holiday travel. PhD Thesis. UK: Bournemouth University.

Golding, P., Murdock, G. (2000). Culture, communications and political economy. $3^{\text {rd }}$ Edition. London: Arnold Publishers.

Hague, B. (2016). What are you worth? The audience for Sale. Retrieved from: http:// www.medialit.org/reading-room/what-are-you-worth-audience-sale\#bio. [Accessed 10 January 2019.]

Hardy, J. (2014). Critical political economy of communications: a mid-term review. International Journal of Media \& Cultural Politics, 10(2), 189-202.

Hayes, D., Lawless, J. (2015). As local news goes, so goes citizen engagement: media, knowledge, and participation in U.S. House elections. The Journal of Politics, 77(2), 447-462.

Lievrouw, L. (2011). Alternative and activist new media. Malden, MA: Polity Press.

McChesney, R. (2015). Rich media, poor democracy: communication politics in dubious times. $2^{\text {nd }}$ Edition. New York: The New Press.

McChesney, R. W., Schiller, D. (2003). The political economy of international communications: foundations for the emerging global debate about media ownership and regulation. United Nations Research Institute for Social Development.

McIntosh, P., Shawn, J. (2017). Converging media: a new introduction to mass communication. $5^{\text {th }}$ Edition. Oxford: Oxford University Press.

Mendez, J. (2010). Data-driven thinking: the emergence of audience selling. Retrieved from: http://adexchanger.com/data-driven-thinking/the-emergence-of-audience-selli ng/. [Accessed 8 May 2018.]

Messing, S., Weisel, R. (2017). Partisan conflict and congressional outreach. Research Report. Washington, D.C.: Pew Research Centre.

Moehler, D. C., Singh, N. (2011). Whose news do you trust? Explaining trust in private versus public media in Africa. Political Research Quarterly, 64(2), 276-292.

Mosco, V. (2008). Current trends in the political economy of communication. Global Media Journal - Canadian Edition, 1(1), 45-63. 
Murdock, G., Gripsrud, J. (eds.) (2015). Money talks: media, markets, crisis. London: Intellect Ltd.

Ndonye, M. M., Ndoro, P., Yieke, F. (2019a). Mediatized horserace political analyses: interrogating the 2017 elections political propaganda in Kenya. Coretrain Journal of Languages, Humanities, Social Sciences and Education, 1(2), 86-96.

Ndonye, M. M., Yieke, F., Ndoro, P. (2019b). Emergence of ethnopolitical journalism in Kenya: lessons from the 2017 televised political analyses shows. Editon Consortium Journal of Media and Communication Studies, 1(1), 36-51.

Oberiri, D. A. (2016). Journalists' perception of news commercialisation and its implication on media credibility in Nigeria. Retrieved from: www.worldscientificne ws.com. [Accessed 8 May 2018.]

Owen, D. (2018). The new media's role in politics. Retrieved from: https://www.bbvaope nmind.com/en/articles/the-new-media-s-role-in-politics/. [Accessed 10 January 2019.]

Peters, C. (2016). Spaces and places of news consumption. In T. Witschge, C. W. Anderson, D. Domingo, A. Hermida (eds.), The Sage Handbook of Digital Journalism, 354-369. London: Sage Publications.

Ray, W. (2014). Why we love bad news more than good news: does the current news negativity bias reflect media our public preferences? Retrieved from: https://www.ps ychologytoday.com/blog/wired-success/201411/why-we-love-bad-news-more-goodnews. [Accessed 10 January 2018.]

Robinson, M. J. (2007). Two decades of American news preferences. Washington: Pew Research Centre.

Roush, C. (2016). Show me the money: writing business and economics stories for mass communication. New York: Routledge Publisher Inc.

Sachdeva, R. (2015). Assessment of advertising effectiveness: a scale validation exercise. Marketing Journal, 9(3), 15-25.

Schudson, M. (2002). The news media as political institutions. Annual Review of Political Science, 5(1), 249-269.

Sonderman, J. (2014). Advertisers buy audiences, not publications or platforms, and data is the key. Retrieved from: https://www.americanpressinstitute.org/publications/repor ts/white-papers/advertisers-audiences-data/. [Accessed 10 January 2019.]

Stiglitz, J. (2017). Towards a taxonomy of media capture. In A. Schiffrin (ed.), The service of power: media capture and the threat to democracy, 9-17. Washington, DC: Centre for International Media Assistance.

Stroud, N. J. (2011). Niche news: the politics of news choice. New York: Oxford University Press.

Tsimonis, G., Dimitriadis, S. (2014). Brand strategies in social media. Marketing Intelligence \& Planning, 32(3), 328-344.

Velarde, A. (2013). Marshall report explores media consumption. Los Angeles, CA.: Daily Trojan. 